\title{
Sosyal Hizmetler Ön Lisans Eğitimi ve Müfredatında Karşılaşılan Sorunlar
}

\author{
DOI: 10.26466/opus.668953
}

*

\author{
Hidir Apak * \\ * Dr. Öğr. Üyesi, Mardin Artuklu Üniversitesi, Sağlik Bilimleri Fakültesi, Mardin/Türkiye \\ E-Posta: hidirapak@artuklu.edu.tr \\ ORCID: $\underline{0000-0002-2330-3093}$
}

\section{Öz}

Bu çalışma, ön lisans sosyal hizmetler programlarında görevli öğretim elemanlarının sosyal hizmetler eğitiminin sorunlarını, müfredat durumunu ve önerilerini derinlemesine ortaya koymayı amaçlamaktadır. Ön lisans mezunu sosyal hizmetler yardımcıları çalışacakları alanlarda büyük bir boşluğu dolduracaklardır ancak tartışılması gereken asıl konu bu bireylerin nasıl daha iyi eğitilmeleri gerekliliğidir. Iş̧te bu çalışma bu soruya öğretim elemanları gözüyle bir katkı sağlamaya çalışmıştır. Araştırmada öğretim elemanlarının sosyal hizmetler eğitimi ile ilgili deneyimlerini ve düşüncelerini anlama ve tanımlamayı içerme gereksinimi duyulduğu için nitel yöntem tercih edilmiştir. Araştırmanın çalışma grubunu farklı meslek yüksekokulları sosyal hizmetler programlarında görevli öğretim elemanlarından gönüllü olarak çalışmaya katılmak isteyen 10 öğretim görevlisi oluşturmuştur. Araştırmanın veri toplama aracı araştırmacı tarafından hazırlanmış olan yapılandırılmış görüşme formudur. Nitel görüşmeler bittikten sonra veri analizine geçilmiş ve ilk olarak görüşmeler ve notlar temize geçirilmiştir. Elde edilen notlar içerik analizi tekniğgi ile incelenmiştir. Elde edilen verilerin kodlanması sonucu, toplamda üç genel tema ortaya konulmuştur. Bu genel temalar; sosyal hizmetler eğitimiyle ilgili karşılaşılan temel sorunlar, sosyal hizmetler müfredatına yönelik görüşler ve sosyal hizmetler eğitim kalitesinin artırlmasına yönelik öneriler şeklindedir.

Anahtar Kelimeler: Meslek yüksekokulu, müfredat, ön lisans, sosyal hizmetler, sosyal hizmetler eğitimi., 


\title{
Problems Encountered in Associate Degree Social Services Education and Curriculum
}

\begin{abstract}
This study aims to reveal in depth the problems, curriculum status and suggestions of the social services education from the point of view of lecturers who are working in associate degree social services programs. Associate degree social services assistants will fill a huge gap in their fields of work, but the main issue to be discussed is how these individuals should be better educated. This study tried to contribute to this question from the perspective of lecturers.

Qualitative method was preferred in the research since it was necessary to include the experiences and thoughts of teaching staff about social services education. The study group consists of 10 lecturers who volunteered to participate in the study voluntarily. The data collection tool is a structured interview form prepared by the researcher. After qualitative interviews, data analysis was conducted and firstly interviews and notes were decoded. The obtained notes were examined by content analysis technique. As a result of the coding of the data obtained, three general themes were revealed. These general themes are basic problems encountered in social services education, views on the social services curriculum, and suggestions for improving the quality of social services education.
\end{abstract}

Keywords: Vocational school, curriculum, associate degree, social services, social services education 


\section{Giriş}

Meslek yüksekokulları (MYO), ön lisans derecesi veren, belirli mesleklere yönelik nitelikli ara insan gücü yetiştirmeyi amaçlayan ve iki yıllık eğitim öğretim sürdüren bir yükseköğretim kurumudur (YÖK, 1981). Yirminci yüzyılın en önemli gelişmelerinden biri olarak kabul edilen ön lisans eğitimi, artan yükseköğretim talebini ve ara insan gücü gereksinimlerini karşılamak amacryla birçok ülkede geniş bir ilgi görerek yaygınlaşmıştır (Ergin ve Yağcl, 2003). MYO'larda verilen eğitim ile bireylere ilgili mesleklerin beklentilerini karşılayacak nitelikte teorik ve uygulamaya dönük bilgi ve beceri kazandırma amacı güdülmektedir (Bozkurt ve Şener, 2013). Aynı zamanda iş dünyası ile mesleki eğitim arasındaki beklentilerin aynı doğrultuda olmasının sağlanması son derece önemlidir. Diğer bir ifadeyle, iş dünyasının beklentileri ile toplumun dinamiğini oluşturan gençlerin geleceğe ilişkin beklentilerin birbiriyle örtüşmesi gerekmektedir (Durnalı, Orakcı ve Özkan, 2018).

MYO bünyesinde kurulan birçok programdan biri de sosyal hizmetler programıdır. Sosyal hizmetler programı; sosyal hizmetler alanında, mesleki yeterlilikler temelinde, ön lisans düzeyinde eğitim öğretim verilen, mesleki beceri ve deneyim kazandırılan, yasal yetkiler çerçevesinde mesleklerini yapabilme sorumluluğunu taşıyan ara elemanları yetiştiren bir diploma programıdır (Apak, 2019). Sosyal hizmetler ön lisans eğitimi eğitim sistemlerine uygun bir şekilde bütün Dünya' da örnekleri olan bir eğitim kademesidir (Tomanbay, 2011: 5).

Türkiye'de sosyal hizmetler ön lisans eğitiminin gelişimi 1960-1980 yılları arası 'denemeler dönemi', 1980-2007 yılları arası 'oluşamama dönemi', 20082013 yılları arası 'hazırlık ve başlangıç' ve 2013 yılı sonrası 'büyüme dönemi' olarak tasnif edilebilir (Apak, 2018). Türkiye'de ilk defa 2008 yılında Anadolu Üniversitesi Açıöğretim Fakültesinde kurulan ve sosyal hizmetler alanında çalışan ara elemanların niteliklerini artırmak, ihtiyaç duyulan yeni ara elemanları yetiştirmek amacı güden (Çay, 2011; Oral, 2017) bu program 2013 sonrasında hem açı öğretim bağlamında hem de örgün eğitim bünyesinde ciddi bir artış gerçekleştirerek günümüze kadar gelmiştir.

ÖSYM (2019) ve Yükseköğretim Bilgi Yönetim Sistemi (2019) verilerine göre sosyal hizmetler programı; üçü açık öğretim fakültesinde ve elli altısı ise örgün eğitim veren meslek yüksekokullarında olmak üzere toplam elli beş 
farklı üniversitede yer almaktadırlar. Elli beş üniversitenin içerisinde bulunan programın yirmisi vakıf üniversitesi programıdır. 2018-2019 eğitim döneminde sosyal hizmetler ön lisans programına 29 bin 351 öğrenci yeni kayıt yaptırmış ve toplam öğrenci sayısı 197 bin 611 sayısına ulaşmıştır. 2018-2019 eğitim öğretim yılında, sosyal hizmetler ön lisans eğitimi veren yükseköğretim programlarında görevli 189 öğretim elemanı bulunmaktadır. Akademisyenlerin büyük çoğunluğunu öğretim görevlileri (167) oluştururken bunu s1rasıyla doktor öğretim üyesi (15) ve profesör (2) kadroları takip etmektedir.

Programın temel amacı, öğrencilere sosyal çalışma alanlarının gerektirdiği bilgi, beceri ve teknik yetkinliği kazandırmak ve karşılaşabilecekleri mesleki sorunlara çözüm üretebilecek nitelikler ile donatılmalarına yardımcı olmaktır. Ayrıca hem sosyal hizmetlerin örgütlenmesi ve uygulanmasında gereksinim duyulan yeni ara elemanlar yetiştirmeyi hem de halen sosyal hizmetler alanında çalışan yardımc personelin niteliklerini geliştirmeyi amaçlamaktadır. Bu doğrultuda, sosyal hizmetler alanlarında çalışan bireyler ile profesyonel olarak çalışan sosyal çalışmacı arasındaki orta kademe insan gücünün yetiştirilmesini amaçlayan eğitim programları uygulanmaktadır. Sosyal hizmetler ön lisans programı, sosyal hizmetler alanlarında istihdam aç1sından ara eleman boşluğunu doldurma işlevini yerine getirmektedir. $\mathrm{Bu}$ programda okuyan öğrenciler genel olarak, sosyal hizmetler alanlarında çalışabilecek nitelikli iş gücü olarak mezun olmaktadırlar.

Sosyal hizmet kurum ve kuruluşlarının ihtiyaç duyduğu nitelikli insan gücünü yetiştiren en önemli kaynaklardan biri olabilecek MYO'lar, mesleki eğitimle birlikte iyi yetişmiş sosyal hizmetler mezunları aracilığıyla sosyal çalışma alanlarında var olan yardımcı ve vasıfsız iş gücünü azaltacaktır. Bunun yanında ülkenin sosyal hizmetler üretimine de önemli katkılar sağlayacaklardir.

Meslek yüksekokulları, gelişmekte ve kalkınmakta olan ekonomiler için önem taşımakla birlikte ülkemizde ne yazık ki çok ciddi sorunları bulunmaktadır (Ünver, Yaylı ve Ceylan, 2009). Bu sorunlardan payını sosyal hizmetler programı da almaktadır. 2013 yılından sonra sosyal hizmetler programında yaşanan kontrolsüz büyüme ve buna bağlı olarak öğrenci kontenjanlarının hızla yükselmesi, açılan programlarda eğitim konusunu çok önemli bir yere taşımaktadır. Hem yeni bir program olması hem de öğrenci sayısının ve programın çok fazla olması eğitimi tartışmayı zorunlu kılmaktadır. 
Ülkemizde meslek yüksekokullarında bulunan programlarının eğitimleriyle ilgili karşılaşılan sorunları ele alan çok sayıda çalışma vardır (Göktürk, Aktaş ve Göktürk, 2013; Kü̧̈ükgöksel ve Akpınar, 2016; Türkeri, 2014; Uçar ve Özerbaş, 2013; Yıldırım, Sertel ve Özmen-Akyol, 2017). Ancak bu bağlamda sosyal hizmetler programı ile ilgili bir çalışmaya rastlanılamamıştır. Sosyal hizmetler programının daha iyi seviyelere gelmesi için var olan ve muhtemel sorunların tespitine ve çözüm önerilerine ihtiyaç duyulmaktadır. Bu bağlamda, eğitim ve müfredatla ilgili mevcut sorunlara yönelik öğretim elemanlarının görüşleri önem taşımaktadır. Uçar ve Özerbaş (2013) MYO'larda görevli öğretim elemanlarının eğitim ve sorunlar hakkındaki düşüncelerini ele aldıkları çalışmaları sonucunda, mesleki ve teknik eğitimde yenilemeye gidilmesini, öğretim elemanlarının mesleki ve teknik eğitimle ilgili şikâyetlerinin önemsenmesi gerekliliğini ve okullarda verimin artırılması gerektiğini vurgulamıştır.

Tüm bu düşüncelerden hareketle bu çalışma, ön lisans sosyal hizmetler programlarında görevli öğretim elemanlarının sosyal hizmetler eğitiminin sorunların, müfredat durumunu ve önerilerini derinlemesine ortaya koymayı amaçlamaktadır. Ülkemizde sosyal hizmetler ön lisans eğitimi ile ilgili yapılan çalışmalar (Apak, 2018; Tomanbay, 2011; Yarcı ve Alpman, 2015) henüz oldukça yetersizdir. Bu çalışmalarda sosyal hizmetler programlarının eğitimi ve müfredatında karşılaşılan sorunlara değinilmemiştir. Bu çalışmanın amacı da bu alanda var olan çalışma sınırlılığı dikkate alınarak literatüre katkı sağlamaya çabalamaktır.

\section{Yöntem}

Araştırmada öğretim elemanlarının sosyal hizmetler eğitimi ile ilgili deneyimlerini ve düşüncelerini anlama ve tanımlamayı içerme (Büyüköztürk, K1liç-Çakmak, Akgün, Karadeniz ve Demirel, 2015, s. 243) gereksinimi duyulduğu için nitel araştırma yöntemi olan fenomenoloi tercih edilmiştir. Fenomenolojik araştırma, araştırmacının katılımclar tarafından tanımlanmış şekliyle bir fenomenle ilgili çeşitli deneyimlerin özüne ulaşılmaya çalışılmaktadır (Giorgi, 2009; Moustakas, 1994 Akt: Creswell, 2014). 


\section{Çalışma grubu}

Araştırmada amaçlı örnekleme yöntemlerinden olan "maksimum çeşitlilik örneklemesi" kullanılmıştır. Maksimum çeşitlilik örneklemesinde amaç; göreli olarak küçük bir örneklem oluşturmak ve bu örneklemde, çalışılan probleme taraf olabilecek bireylerin çeşitliliğini maksimum derecede yansıtmaktır (Yıldırım ve Şimşek, 2013: 136). Araştırmanın nitel bölümüne katılan akademisyenlerin belirlenmesinde maksimum çeşitlilik yöntemi çerçevesinden bakılarak; örgün öğretim kurumlarından sosyal hizmetler programlarının bölüm başkanları seçilmiştir. Sosyal hizmetler programının 55'i örgün eğitim veren meslek yüksekokullarında yer almaktadırlar. Öncelikle açıöğretim ve uzaktan eğitim veren öğretim kurumları hariç e-posta adresine ulaşılabilen (web sitesinde bulunan) 45 sosyal hizmetler programı bölüm başkanına bilgilendirme e-postası atılmış ve bu mesaja dönüş yapan öğretim elemanları araştırma kapsamına dâhil edilmiştir.

Araştırmanın çalışma grubunu farklı sosyal hizmetler programlarında görevli öğretim elemanlarından gönüllü olarak çalışmaya katılmak isteyen 10 öğretim elemanı oluşturmuştur. Yapılan araştırmada 10 farklı programda katılımcıya ulaşılarak programların neredeyse \%20'sine ulaşıldığı ifade edilebilir.

\section{Veri toplama aract}

Araştırmanın veri toplama aracl; araştırmacı tarafından araştırmanın amacına uygun olarak hazırlanmış olan yapılandırılmış görüşme formudur. Soru formu oluşturulurken deneyim veya davranış, düşünce, inanç ve duygu sorularının (Kümbetoğlu, 2012) yer almasına dikkat edilmiştir. Soru formu oluşturulurken iki alan uzmanından destek alınmıştır. Soruların araştırmanın amacı ve alt amaçları bağlamında olup olmadığı incelenmiş ve soru formunun taslak hali oluşturulmuştur. Soru formu oluştuktan sonra sosyal hizmetler programından bir akademisyenle pilot görüşme yapılmıştır ve bu görüşme sonucunda soru formuna son hali verilmiştir. Yapılandırılmış soru formu 6 temel soru ve bu temel soruların altında oluşturulan sonda sorulardan oluşmaktadır. 


\section{Verilerin analizi}

Nitel veriler, öğretim elemanların 5'i ile yüz yüze görüssmeler yapılarak, 3'ü ile telefonla ve 2'si ile de mail yoluyla toplanmıştır. Görüşmeler, Şubat ve Haziran 2019 tarihleri arasında gerçekleştirmiştir. Nitel görüşmeler bittikten sonra veri analizine geçilmiş ve ilk olarak görüşmeler ve notlar temize geçirilmiştir. Elde edilen notlar içerik analizi tekniği ile incelenmiştir. İçerik analizi; bir içeriği inceleme ve anlama tekniğidir. Bu tekniğe göre araştırmacı ilk olarak tutulan notlar okumuş, verileri tek tek inceleyerek bazı notlar almış sonrasında ise içeriğe uygun kod ve kategoriler oluşturmuştur. Elde edilen kod listesi ve kodlama içeriğinin dökümü alınarak üç alan uzmanı incelemesine tabi tutulmuştur. Uzmanların görüşleri doğrultusunda tema isimleri ve kodlamalarda önerilen düzeltmeler yapılmıştır.

Elde edilen kod frekansları (f); katılımcların, sorulan sorulara göre neyi kaç defa ifade ettiklerini göstermektedir. Dolayısıyla bulunan frekanslar, katılımcı sayısın değil analiz yoluyla saptanan ifadelerin sıklığını göstermektedir. Tematik bir analizin yanında katılımcılardan doğrudan alıntılar da yapılmıştır. Doğrudan alıntılarda öğretim elemanlarına ait bilgiler sadece katılımcı numaraları (ÖE1, ÖE8 gibi) ile ifade edilmiştir.

Yapılan araştırmada geçerlik ve güvenirlilik bağlamında elde edilen veriler inandırıcılık, aktarılabilirlik ve uzman görüşü ile sağlanmıştır. Araştırılan konuya ilişkin farklı bakış açılarının, farklı algıların ve farklı deneyimlerin konmasına gayret edilmiş, inandırıcılığın artmasına katkıda bulunulmaya çalışılmıştır. Ayrıca uzman incelemesi bağlamında alanında yetkin üç uzman, araştırmacı ile birlikte değerlendirme yapmıştır. Uzmanlar tarafından literatür ışığında belirlenen kavramsal çerçeveye uygun bir şekilde analizler edilmiştir. Aktarılabilirlik bağlamında elde edilen verilerle ortaya çıkan kavram ve temalar doğrultusunda katılımcıların ifadelerine sadık kalınarak doğrudan alıntılara yer verilmiştir.

\section{Bulgular}

Bu bölümde, araştırmaya katılan öğretim elemanlarından elde edilen bulgular tablolar hâlinde sunulup yorumlanmaktadır. Elde edilen verilerin kodlanması sonucu, toplamda üç genel tema ortaya konulmuştur. Bu temalar Şekil 
1'de gösterilmiştir. Bu genel temalar; sosyal hizmetler eğitimiyle ilgili karş1laşlan temel sorunlar, sosyal hizmetler müfredatına yönelik görüşler ve sosyal hizmetler eğitim kalitesinin artırılmasına yönelik öneriler şeklindedir. Söz konusu 3 temanın altında kategoriler ve kodlar bulunmaktadır.

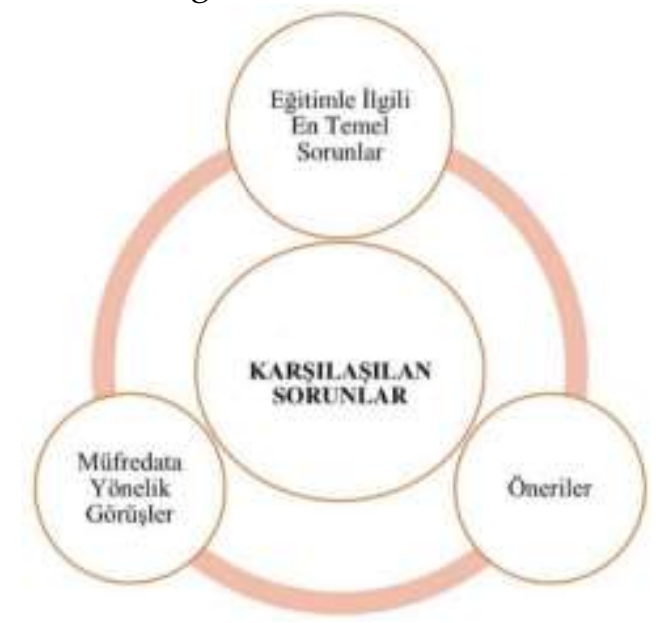

Şekil 1. Nitel Veri Analizi Sonucu Oluşan Temalar

\section{Sosyal Hizmetler Eğitimiyle İlgili En Temel Sorunlar}

Bu tema altında öğretim elemanlarına sosyal hizmetler ön lisans eğitimiyle ilgili en temel sorun alanlarının ne olduğu sorulmuştur. Katılımcların bu temada, bireysel düşüncelerini ve eğitim verirken edindikleri deneyim ve izlenimlerini yansıttıkları görülmüştür.

Araştırmaya katılan öğretim elemanlarının büyük çoğunluğu karşılaşılan sorunları 'eğitimin içeriğgi' ( $\mathrm{f}=17$ ) ve 'kimlik ve istihdam' ( $\mathrm{f}=16)$ üzerinden tanımlamışlardır. Tablo 1'e bakıldığında katılımcların eğitimde karşılaştıkları sorunlar için diğer kategoriler 'akademisyen merkezli' (f=12), 'YÖK merkezli' $(\mathrm{f}=12)$ ve 'öğrenci merkezli' ( $\mathrm{f}=7$ ) kategorileridir.

Ön lisans eğitimi ile ilgili karşılaştıkları temel sorunlara yönelik görüşlerini belirten öğretim elemanlarının bir kısmı eğitimin içeriği $(\mathrm{f}=16)$ ile ilgili sorunlar yaşadıklarını ifade etmişlerdir. Tablo 1'de bu durumu da daha çok staj $(\mathrm{f}=8)$ ve müfredat sorunu $(\mathrm{f}=5)$ üzerinden ifade etmektedirler. 
Tablo 1. Eğitimin içeriği bağlamında karşılaşılan sorunlar

\begin{tabular}{ll}
\hline Eğitimin İçeriği & f \\
\hline Staj sorunu & 8 \\
\hline Kaynak kitap sıkıntısı & 1 \\
\hline Müfredat sorunu & 5 \\
\hline Teorik - uygulama uyuşmazlı̆̆ & 3 \\
\hline Toplam & 17 \\
\hline
\end{tabular}

ÖÖ1 staj uygulaması bağlamında kamu kurum ve kuruluşlarıyla sorunlar yaşandığını “Öğrencilerimizin staj problemi yaşamalarındaki temel neden ön lisans ögrencilerine kamu kurum ve kuruluşlarmm çok sıcak bakmamasından kaynaklı yer bulamama" şeklinde ifade ederken; ÖÖ7 ise bu durumu şu şekilde ifade etmiştir: "Ĕğitim sürecinde staj yerlerinin öğrencilere ön lisans olduğu için stajyer olarak kabul etmeme üzerine eğilim göstermesi eğitim sürecinin uygulamalarla desteklenmesi acısından olumsuzluklar teşkil etmektedir."

Müfredat sorunu da katılımcllar dile getirirken daha çok müfredat birlikteliğinin olmaması üzerinden tanımlamışlardır:

- "Türkiye'de sosyal hizmet ön lisans programlarmm en temel sorunlarn arasinda lisans eğitiminde olduğu gibi her üniversitenin kendine göre bir müfredat oluşturmaya çalışması ve müfredat birliğinin olmamasının olduğu kantsindayım." (ÖÖ8)

- "Ders müfredatlarmmn üniversiteden üniversiteye çok farklllık göstermesi bir sorun olarak görülebilir." (ÖÖ5)

Tablo 2' de kimlik ve istihdam kategorisi altında en fazla üzerinde durulan konu sosyal hizmetler ön lisans eğitiminin ne olduğu ve belirsizliği üzerinden şekillenmiştir.

Tablo 2. Kimlik ve istihdam sorunlam

\begin{tabular}{ll}
\hline Kimlik ve istihdam & $\mathbf{f}$ \\
\hline Görev tanımının (Unvan) olmaması & 2 \\
\hline İstihdamın olmaması & 4 \\
\hline Atama olmayışı & 2 \\
\hline Kimlik ve amaç sorunu & 3 \\
\hline Lisansın alt alanı gibi görünmesi & 5 \\
\hline Toplam & 16 \\
\hline
\end{tabular}


ÖÖ10 bu durumu kimlik ve amaç sorunu ( $\mathrm{f}=3$ ) ve sosyal hizmet lisansinm altı $(\mathrm{f}=5)$ gibi görünmesi bağlamında şu şekilde ifade etmektedir:

- "Kimlik ve amaç sorunu en büyük sorundur. Aslında bu programlarm açılış amacı, neden açıldığı, kim olduğu konuları net değildir... Program mezunlarmın nereden, ne olarak çalışacak olabilmelerinin net olmaması da bir başka sorun... Programın sosyal hizmet lisans bölümü alt programı olarak görülmesi de bu anlamda bir problem olarak karşımızda durmaktadır. Yani biz zannediyoruz ki sosyal hizmetler ön lisans deyince işte hemen aklmiza sosyal hizmet lisans programlarımın yardımcısı veya iki yıllı̆̆ı gibi bir şey anlaşıllyor. Hâlbuki böyle değil çok farkh programlar olduğunu ifade edebiliriz."

Kimlik ve istihdam kategorisi altında atama $(\mathrm{f}=2)$ ve istihdamın olmayışı $(\mathrm{f}=4)$ da eğitimde karşılaşılan sorunların başında geldiğini ifade eden katılımcılara rastlanılmaktadır. ÖÖ7 bu durumu “Ön lisans sosyal hizmetler bölümünün halen KPSS ile atamasının olmayışı ögrenciler acısından endişe oluşturmakta ve bölümü okuma şevk ve heyecanını azaltmaktadır" şeklinde ifade etmektedir. ÖÖ3 ise bu durumu "Ön lisans için herhangi bir atama kadrosunun verilmemesi ve görev tanımının belirlenmemesi" şeklinde dile getirirken ÖÖ5 kodlu katılımc ise benzer şekilde "Kamu sektöründe sosyal hizmet ön lisans mezunlarna yer verilmemesi ve meslek unvanmin henüz belirlenememiş olması"nı en büyük sorun alanlarından biri olarak ifade etmektedir.

Araştırmada bazı katılımcılar eğitimde karşılaşılan sorunları ifade ederken akademisyen merkezli ( $\mathrm{f}=12$ ) sorunlara da vurgu yapmışlardır. Tablo 3'te görüldügü üzere 'Alandan olmayan akademisyenlerin' ( $\mathrm{f}=7$ ) var olması, ‘akademisyen eksikliği ( $\mathrm{f}=3$ ) ve 'üniversite yönetim ve akademisyenlerin dar bakış açıları (f=2) gibi kodlara başvurmuşlardır.

Tablo 3. Akademisyen merkezli sorunlar

\begin{tabular}{ll}
\hline Akademisyen merkezli & f \\
\hline Akademisyen eksiklĭgi & 3 \\
\hline Alandan olmayan akademisyenler & 7 \\
\hline Akademisyenlerin dar bakış açları & 2 \\
\hline Toplam & 12 \\
\hline
\end{tabular}

Katılımcıların görüşlerine ilişkin aşağıda örnekler sunulmuştur:

- "Sorunlarm bir kısmı nitelikli sosyal hizmet alan kökenli akademisyen eksikliği ve üniversite yönetim ve akademisyenlerin dar bakış açılarından kaynaklanmaktadır." (ÖÖ6) 
- "En temel sorun da liyakatli ve yeterli öğretim elemanlarının olmayışıdır." (ÖÖ9)

- "Sosyal hizmetler programlarında eğitim veren öğretim elemanlarmın alan bilgisine sahip olmamaları veya alandan uzak kişiler olması ve ilgili müfredatlardan uzak olması başka bir sorun olarak karşımıza çıkmaktadır... Bu durum verilen eğitimin niteliksiz olması öğrencilerin de dolayısıyla niteliksiz olarak yeterince eğitim almadan mezun olabilmelerine neden olabilmektedir."(ÖÖ10)

Ön lisans eğitiminde karşılaşılan problemleri tanımlarken akademisyenlerin bir kısmı olaya daha makro bir bakış açısıyla yaklaşarak YÖK merkezli $(\mathrm{f}=12)$ sorunları aktarmışlardır.

Tablo 4. YÖK merkezli sorunlar

\begin{tabular}{ll}
\hline YÖK merkezli & $\mathbf{f}$ \\
\hline Açı öğretimin olması & 2 \\
\hline Abartılı kontenjanlar & 2 \\
\hline DGS'de haksız dağılım & 5 \\
\hline Çok sayıda programın olması & 3 \\
\hline Toplam & 12 \\
\hline
\end{tabular}

Tablo 4'te görüldüğü üzere daha çok 'Dikey Geçiş Sınavı'nda (DGS) haksız dağılım' (f=5), 'çok sayıda programın olması' ( $\mathrm{f}=3)$, 'abartılı kontenjanlar' ve 'açıköğretimin olması' ( $\mathrm{f}=2$ ) gündeme getirilmiştir. DGS konusunda pek çok sorun yaşadıklarını ifade eden bir katılımcı "DGS ile birçok bölümden sosyal hizmete geçiş varken; sosyal hizmetler programından diğer bölümlere geçiş sınırlı sayıda söz konusu" (ÖÖ5) olma durumunu dile getirmiştir. Başka bir katılımcı ise sosyal hizmetler alanlarıyla alakası olmayan diğer program mezunlarıyla DGS'de yarışmalarının adaletsizliğine dikkat çekerek düşüncelerini şöyle aktarmıştır: "Programdan mezun öğrenciler DGS ile kendi alanlarıla ilgi doğrudan ilişkili olan bir bölüm olan sosyal hizmet lisans bölümüne geçmek istediklerinde pek çok farklı program mezunu ile yarışmaktadırlar. Ancak bu programların çoğu sosyal hizmet lisans ile alakası olmaması bir sorun oluşturmaktadır." (ÖÖ4)

Sosyal hizmetler eğitimi ile ilgili sorunlardan birinin de açıöğretim modelinin uygulanması olarak gösterilmiştir. ÖÖ2 bu durumu "Açı öğretimden bu bölümün okutulması kadar mantıksız bir şey olduğunu düşünmüyorum" diyerek net bir şekilde ortaya koymuştur. Daha çok Yüksek Öğrenim Kurumu'nun 
elinde olan kontenjan sorunu ve program fazlalığı da dile getirilen sorunlardan bazılarıdır. Bu tarzda düşünen katılımcılar düşüncelerini şu şekilde ifade etmektedirler:

- "Ayrica üniversitelerde kontrolsüz bir şekilde sosyal hizmet bölümlerinin açılması da ilerde sosyal hizmet ön lisans mezunu olan kişilerin istihdamında sorunlar yaşamasma neden olmaktadır." (ÖÖ8)

- "Çok fazla ön lisans programmmn olması bir sorundur." (ÖÖ9)

- "Son yillarda sayısı gittikçe artan sosyal hizmetler ön lisans programlarmm yaygınlaşması ciddi bir sorun olarak karşımızda durmaktadır." (ÖÖ5)

Tablo 5. Eğitimle ilgili öğrenci merkezli sorunlar

\begin{tabular}{ll}
\hline Öğrenci Merkezli Sorunlar & f \\
\hline Bilinçsiz tercihler & 3 \\
\hline Öğrenci isteksizlĭgi & 3 \\
\hline Düşük puanlı öğrenci & 1 \\
\hline Toplam & 7 \\
\hline
\end{tabular}

Araştırmaya katılan öğretim elemanlarının bir kısmı eğitimde karşılaşılan sorunları 'öğrenci merkezli' ( $\mathrm{f}=7$ ) bağlamında ele almışlardır. Burada daha çok 'öğrenci isteksizliği' ( $\mathrm{f}=3$ ), 'bilinçsiz yapılan tercihler' ( $\mathrm{f}=3$ ) ve 'düşük puanlı öğrenci' ( $\mathrm{f}=1$ ) profili gündeme getirilmiştir. Bu alandaki görüşlere ilişkin örnekler aşağıda verilmiştir:

- "Öğrencilerin yanlıs ve eksik yönlendirilerek bu alanı tercih etmeleri ve kendilerini geliştirmedeki isteksizlikleri ciddi bir sorundur." (ÖÖ6)

- "Bilinçli yapılmayan tercihler eğitim önündeki engellerden biri. Burada söylemek istediğim öğrenciler bu programı tercih ederken kulaktan doğma bilgiler ile tercih ediyorlar. Aslinda bu programdan mezun olduktan sonra dâhil olacaklarn iş alanlarının kendileri için çok uygun olmadığım anlayınca bu meslekten soğuyorlar." (ÖÖ1)

İşsizlik ve istihdam sorunu sosyal hizmetler mezunu bireylerin karşılaştığı sorunların başlarında gelmektedir. Tablo 6'da bu bağlamda akademisyenlere var olan bu soruna yönelik eğitim kalitesinin bir etkisinin olup olmadığı sorulmuş ve büyük çoğunluk $(n=8)$ etkinin var olduğunu iddia etmiştir. 
Tablo 6. İşsizlik ile sosyal hizmetler programlarnın eğitim kalitesi ve yeterliliklerinin etkisine ilişkin görüşleri

\begin{tabular}{lll}
\hline Soru & Evet (n) & Hayır (n) \\
\hline $\begin{array}{l}\text { Sosyal hizmetler programlarının eğitim kalitesi ve yeterliliklerinin işsizlik } \\
\text { sorununa etkileri var mıdır? }\end{array}$ & 2 & 8 \\
\hline
\end{tabular}

Eğitimin işsizliğe bir etkisinin olduğunu düşünen katılımcılar bu durumu da daha çok açıöğretimin var olması, her yıl binlerce mezun verilmesi, öğrencilerin kendilerini geliştirmemeleri, akademisyenlerin işlerini doğru yapmamaları ve eğitim sistemindeki bozukluklarla ilişkili açıklamaktadırlar. Katılımclların bu konudaki görüşlere ilişkin örnekler şöyledir:

- "Eğitim kalitesi bütün meslekler için geçerli ama en büyük sorun açık öğretim sosyal hizmet mezunu binlerce sosyal çalışmacı adayı olmasından kaynaklı işsizlik artmaktadır. Ayrıca bölüm dışı akademik personelin özellikle sosyal hizmet bölümlerine ya da diğer bölümlere doldurulmastyla var olan kalite gittikçe de düşürülmektedir." (ÖÖ3)

- "İşsizlik sayısının artması bazı faktörlere dayandırılabilir. Örneğin kamu atamalarında bu bölüm mezunlarma yer verilmemesi gibi. Diğer bir önemli faktör ise başta ön lisans sosyal hizmet olmak üzere sosyal hizmet mesleğinin kendini yeterince topluma kabul ettirememesidir. Çünkü bir mesleğin sayginliğı onun toplumdaki algisindan büyük ölçüde etkilenmektedir. Bu noktada özellikle STK'larm sosyal hizmet mezunlarından yararlanması belki biriken işsiz mezun sayısin azaltabilecektir. Diğer taraftan mezunlarm mezuniyet sonrası kendini geliştirmeleri ve özellikle STK ve STÖ'lere yönelmeleri önem taşımaktadır." (ÖÖ5)

- "Sosyal hizmetler programlarmm eğitim kalitesi ve yeterlilikleri elbette ki diğer sorunlar kadar olmasa da işsizliğe etki etmektedir. Alanı tanımayan yanlış yönlendirmelerle bölüme gelip iki yıl boyunca kendisine hiçbir şey katmadan, kendini geliştirmeden mezun olan yığınlar elbette ki karşılaşacakları en temel sorun işsizlik olacaktır. Mevcut hocaların niteliksiz olması, çoğunun alan dışı olması, hocalarm odak noktalarının sadece derse girip çıkmak olduğu onun dışından sadece kendilerini akademik olarak yükselmek gibi dertlerinin olduğu göz önüne alınd-ğında öğrencileri doğru eğitemedikleri ve iyi yönlendiremedikleri ortaya çıkmaktadır. Bütün bunlar toplandığında mevcut sorunların yanı sıra eğitim kalitesi ve yeterliliğinin ne derece önemli olduğu oraya çıkmaktadır." (ÖÖ6)

Bazı katılımcılar ise işsizlik sorununun eğitimden bağımsız olduğunu ifade etmektedir. ÖÖ9 istihdamın eğitimle bir ilişkisi olmadığını şu şekilde 
ifade etmiştir: "Ülkemizde istihdam olanaklarmmn oluşturulmasında eğitim kalitesine ve yeterliliklere bakılmadığından herhangi bir etkisi olmadığını düşünüyorum." ÖÖ8 ise benzer şekilde "Alman eğitime bakuldığında birey ilerde mesleğini icra edebilecek yeterli donanımlara sahip olmaktadır. Dolayısıyla program içerisinde verilen eğitimin bunda çok az bir etkisi vardır. İstihdam noktasında herhangi bir bağlantılarının olmadığı düşüncesindeyim" diyerek eğitim ile istihdam arasında bir bağın olmadığına vurgu yapmıştır.

\section{Sosyal Hizmetler Müfredatına Yönelik Görüşler}

Sosyal hizmetler müfredatı ile ilgili görüşler ve yaşanan sorunlar üzerinden görüşmecilere yöneltilen sorular; karşılığı aranan ve nitel araştırma merkezlerinden olan bir tema olarak karşımıza çıkmaktadır. Bu bölümde; öğretim elemanlarının ön lisans müfredatının yeterliliğine ilişkin görüşleri ve var olan müfredatlarını revize kriterleri olmak üzere iki alt tema belirlenmiştir.

Öğretim elemanlarının çoğunluğu $(n=6)$ müfredatlarını yetersiz görmektedir. İki öğretim elemanı yeterli görürken iki öğretim elemanı ise bu konuda net bir fikir ortaya koymamıştır. Tablo 7'de görüldügü gibi öğretim elemanlarının bir kısmının müfredatla ilgili tutumlarının olduğu ve bu tutumların çoğunluğunun 'olumsuz' olduğu tespit edilmiştir.

Tablo 7. Ön lisans müfredatının yeterliliğine ilişin görüşler

\begin{tabular}{llll}
\hline Kategoriler & f & Kategoriler & f \\
\hline 1. Yeterli & $\mathbf{2}$ & 2.Yetersiz & \\
\hline & & Uygula alanı olmaması & 1 \\
\hline 3. Kararsız & Teorinin yoğun olması & 5 \\
\hline Kendimi yeterli görmüyorum & 1 & Süpervizör eksikliği & 3 \\
\hline Üniversite bazlı bakılabilir & 2 & Özgün değil & 4 \\
\hline & & Öğrenci profiline uygun değil & 3 \\
\hline & Batı merkezli & 2 \\
\hline & Müfredatlar arası farklılıllar & 3 \\
\hline
\end{tabular}

Sosyal hizmetler müfredatını yetersiz gören katılımcıların görüşleri daha çok teorinin yoğun olması $(\mathrm{f}=5)$ bağlamında gerçekleşmiştir. Bu görüşü destekler nitelikte sorulan "Programınızda okutulan derslerin ağırlıkları ne şekildedir? sorusuna öğretim elemanları genellikle alan derslerinin ve teorik derslerin yoğunlukta olduklarını ifade etmişlerdir. 
- "4 dönem boyunca toplamda gösterilen 32 dersin 21 tanesi alan dersi ve 11 tanesi alan dışı dersidir. Kuramsal dersler 3 tane ve uygulama dersi ise 2 tanedir." (ÖÖ1)

- "Dersler ağırlikl olarak alan dersleri ve kuramsaldır. Uygulamal derslere daha çok yer verilmesi gerektiğini düşünüyorum" (ÖÖ2)

- "Ağırlık alan dersleridir. Uygulamalı ders bulunmamaktadır." (ÖÖ4)

- "Programımızda okutulan derslerin çeşitliliğine bakıldtğında derslerin, alan dersleri, kuram dersleri ve uygulamal derslerden oluştuğu görülmektedir. Dolayısıyla ders dağılımının uygun olduğunu düşünmekteyim." (ÖÖ5)

Sosyal hizmetler müfredatını yetersiz gören katılımcların bir kısmı ise müfredatı özgün olmaması ( $\mathrm{f}=4)$, öğrenci profiline uygun olmaması ( $\mathrm{f}=3)$, süpervizör eksikliği $(\mathrm{f}=3$ ) ve müfredatlar arast farklliklar ( $\mathrm{f}=3$ ) üzerinden düşüncelerini şekillenmiştir. Katılımcıların bu konudaki görüşlerine ilişkin örnekler şöyledir:

- "Sosyal hizmetler eğitim müfredatlar uygulama alan ve yetersiz altyapıdan kaynaklı sahadaki uygulamalardan bağımsız teorik eğitimle verilmektedir. Çünkü sahada çalışan alanında uzmanlaşmış ve Sosyal Hizmet mezunu meslek elemanı yetersiz, birçok ilçede çalışan sosyal hizmet uzmanı yok, bu nedenle sağliklı uygulama eğitimi ve desteği veren meslek elemanı yetersiz." (ÖÖ3)

- "Sosyal hizmet müfredatı yeterli değildir. Müfredatlar genel olarak lisans müfredatlar ile benzerlik göstermektedir. Ön lisans düzeyine özgün öğrenci profili dikkate alnarak yeni müfredat belirlenmelidir." (ÖÖ4)

- “Türkiye'de sosyal hizmetler eğitiminin müfredatı kesinlikle yeterli değildir. Bu sorun sadece sosyal hizmetlerde değil hemen hemen bütün sosyal bilimlerde mevcuttur. Avrupa merkezci, batıcl, pozitivist ve seküler eğitim müfredatı anlayışı hâkimdir. Daha çok batı kaynaklarının sadece çevirisi yapılarak müfredatımıza entegre edilmektedir" (ÖÖ6)

- "Türkiye'de sosyal hizmet müfredatı teorik derslerinin yaninda uygulamal derslere de çok fazla ihtiyaç duymaktadır."(ÖÖ8)

- "Genel olarak değerlendirildiğinde yeterli değil. Müfredatta programdan programa farklılıklar olduğunu görüyoruz... Bu anlamda bir sorun karşımıza çıkıyor. Yeterli değil ve farkl. Herkes aslinda yani öğrencinin bu kimlik, amaç, neden gibi unsurlarına değil de kendi içinde sahip olduğu, özelliklerine göre ders belirliyor. Bu da bir birliğin, amacm belirlenmesini zorlaştırabiliyor." (ÖÖ10)

Müfredatların yeterli olduğunu düşünen ÖÖ2 düşüncelerini "Müfredatın 2 yıllıklar açısından yeterli olduğunu düşünüyorum" şeklinde açıklarken; ÖÖ9 ise 
bir şerh düşerek "Türkiye'de benim incelediğim üniversitelerin büyük çoğunluğunda eğitim müfredatınm yeterli olduğu görüşünü taşımakla beraber, uygulamaya biraz daha ağırlık verilmesi gerektiğini düşünüyorum" diyerek düşüncelerini ifade etmiştir.

Müfredatların yeterliliği konusunda net bir tavır ortaya koymayan ÖÖ5 ise bu durumun üniversitede üniversiteye göre değişebileceğini şöyle aktarmıştır: "Ders müfredatının ülkemizde yeterliliği konusunda üniversite bazlı değerlendirme yapmak daha doğru olacaktır. Bazı üniversitelerin ders müfredatlar yeterliyken diğer bazı üniversitelerin yetersiz ve alan uygulamalarında çok yararl olmayacağı düşünülen bazı dersler yer almaktadır." Benzer olarak kendisini bu konuda yeterli görmeyen ÖÖ1'de yeterliliğe ilişkin nötr bir tavır takınmıştır: "Bu konuda şu aşamada görüş belirtmem çok yerinde olmayabilir çünkü kendimi bu alanda henüz yeterli seviyede görmemekteyim."

Görüşülen katılımcıların hepsi müfredatlarını bir kez da olsa revize ettiklerini ifade etmişlerdir. Müfredatlarını "Dersler hemen hemen 2 yılda bir revize edilmektedir" (ÖÖ6) şeklinde iki yılda bir revize ettiklerini ifade eden akademisyenler olduğu gibi derslerin "Müfredatın her yılsonunda bölüm hocalarıla beraber revize edildiğini" (ÖÖ7) ifade eden öğretim elemanları da vardır.

Müfredatların sık sık değiştirilmesinin çeşitli sorunları içinde barındırdığını ÖÖ10 şu şekilde ifade etmiştir:

- “Çok sık değiş̧miyor. Bunun temel nedeni değişiklik yapildığında 2-3 yıl zorunlu olarak zorlamasıdır. Çünkü değişiklikle birlikte bütün sistem baştan aşağı değiş̧iyor. Programda öğrenci dersleri alttan aldığında, öğrenci mezun olamayacak duruma geliyor. Kaldı ki alışılagelmiş derslerin dışında işte bu dersi kaldıracak değiş̧tirme dediğinizde diğer hocaları itirazlarıla karşılaşabiliyorsunuz. Ki bu sorunlar ortaya çıkıyor... Ancak belli bir süre çok sık değiştirmemekle birlikte belli bir süre aldığımı geri bildirimlerle müfredatımı güncellemekteyiz... Bu müfredata geçişte de çok sik sorun yaşıyoruz."

Öğretim elemanlarının müfredat değişiminde hangi kriterler göre hareket ettikleri Tablo 8'de yer almaktadır. 
Tablo 8. Müfredatlarn revize kriterleri

\begin{tabular}{llll}
\hline Kategoriler & f & Kategoriler & f \\
\hline 1. Öğrenci Merkezli & & 3. MYO Merkezli & 1 \\
\hline Daha iyi eğitim arzusu & 9 & Müdürlere göre & 1 \\
\hline Mesleklerinde faydah & 5 & AKTS ve krediye göre & 1 \\
\hline Güncel sorun ve gelişmeler & 3 & Diğer MYO'larda var mı? & 3 \\
\hline Toplam & 17 & Toplam & $\mathbf{4}$ \\
\hline 2. Akademisyen Merkezli & $\mathbf{f}$ & 4. DGS Merkezli & $\mathbf{1}$ \\
\hline İstişare sonucu & 5 & & \\
\hline Vermek istedikleri derslere göre & 4 & 5. Kriter yok & \\
\hline Toplam & 9 & & \\
\hline
\end{tabular}

Akademisyenler, müfredatları revize kriterlerine yönelik verdikleri yanıtlardan en sık görülenleri beş kategori altında toplanmıştır. Katılımcıların revize kriterlerini en sık daha iyi eğitim arzusu ( $f=9$ ), öğrencilerin mesleki yaşamlarında daha faydalı olmaları $(\mathrm{f}=5)$, güncel sorun ve gelişmelere bağlı olarak ( $\mathrm{f}=3$ ) ve öğrenci merkezli $(\mathrm{f}=17)$ bir tavırda dile getirmişlerdir. ÖÖ7 ve ÖÖ1 bu durumu şu şekilde ifade etmiştir:

- “Bölüm hocalarıla beraber dersin öğrenciler üzerinde katkı düzeyi ölçülerek gözden geçirilmekte ve AKTS, mezuniyet kredileri dikkate alnnarak revize edilmeye çalısıllmaktadır. Türkiye'de sosyal hizmet eğitimi müfredatı değişen sosyal sorunlar kapsaminda revize edilmeli ve güncellenmelidir." (ÖÖ7)

- "Bizler bu programı revize ederken temel kriterimiz öğrencilere sosyal hizmet eğitimini daha yoğun bir şekilde ve her dönem birbirini takip eden içerikteki dersleri koyarak yaptık." (ÖÖ1)

Katılımcların bir kısmı ise müfredatlarını revize ederken akademisyen merkezli (f=9) bir tavır takınıldığını ifade etmektedir. ÖÖ2 bu durumu "Genelde yılda bir eklememiz gereken ya da çıkarmamı gereken dersleri hocalarla istişare edip bir karara bağlıyoruz" şeklinde dile getirmiştir.

Bazı katılımcılar ise birden fazla kriteri göz önüne alarak revize işlemlerini yaptıklarını ifade etmişlerdir. Buna ilişkin örnekler şöyledir:

- "Ders programı revize edilirken; bizden hangi dersin neden değiştirilmek istendiği, yeni eklenecek dersin diğger üniversite sosyal hizmet ön lisans programlarında hangi sıklıla yer aldı̆̆ına bakılarak değerlendirilmektedir." (ÖÖ5)

- "Dersler daha çok hocalarnn ilgi ve yeterlilikleri kriteri ve öğrencilerin dikey geçiş yapacakları zaman gittiği üniversitelerde daha fazla dersten muaf olacakları kriterlerine göre yapılmaktadır. Ayrica güncel sorunlar ve gelişmelere bağh olarak bazı değişikliklere gidilebilmektedir." (ÖÖ6) 
- "Meslek yüksekokulundaki müfredat öğrencilerin daha fazla verim alması amacryla ihtiyaca göre güncellenmektedir... Bu da öğrencilerin dönem içerisinde ders verimlilikleri göz önünde bulundurularak müdürlükle koordineli olacak şekilde güncellenmektedir." (ÖÖ8)

- "Programda yer alan dersler ve içerikler ilgili hocalar tarafindan oluşturulduğu için alan derslerine ağırlık verilmiştir. Diğer bütün programlarda olan alan dışı dersler sınırl sayıda tutularak öğrencilerin yeterli bir donanımla ilgili programı bitirmelerine olanak sağlanmaya çalışılmıştır. Diğer taraftan öğrencilerin gerek yatay geçiş, gerekse de dikey yapmalarına olanak sağlayacak şekilde programımız oluşturulmuştur." (ÖÖ9)

\section{Sosyal Hizmetler Eğitim Kalitesinin Artınlmasına Yönelik Öneriler}

Akademisyenlerin sosyal hizmetler eğitim kalitesinin artırılmasına yönelik en fazla müfredata ilişkin önerilerin ( $(\mathrm{f}=30)$ ifade edildiği bunu YÖK'e ve üniversite yönetimlerine yönelik tavsiyeler $(\mathrm{f}=25)$ ile istihdama yönelik önerilerin $(\mathrm{f}=14)$ izlediği görülecektir.

Tablo 9. Müfredata yönelik öneriler

\begin{tabular}{ll}
\hline Müfredat bağlamında & f \\
\hline Uygulama dersleri daha fazla olsun & 10 \\
\hline Ortak bir müfredat olsun & 5 \\
\hline Yerel dinamiklerle bir müfredat & 4 \\
\hline Ortak toplantılar & 7 \\
\hline Öğrenci düzeyi ve merkezli olsun & 3 \\
\hline Son dönem bitirme projesi olmalı & 1 \\
\hline Toplam & 30 \\
\hline
\end{tabular}

Müfredata yönelik önerilerin başında uygulama derslerinin fazla olması gerektiği düşüncesi ön plana çıkmaktadır. Nitekim ÖÖ1 "Şu an için söyleyebileceğim uygulama derslerinin daha fazla olması gerektiğidir" şeklinde kendini ifade ederken ÖÖ8 "Dolayıstyla Türkiye'de yer alan sosyal hizmetler programlartnın uygulamalı derslerinin sayısının artırlması gerektiği düşüncesindeyim. Sosyal hizmet mesleği sadece kişilerin bireysel olarak teorik dersleri alp uygulamaya döktüğü bir disiplin değildir. Okulda öğrenmiş olduğu teorik bilgilerin pratiğe dökülmesi noktasında uygulamaya da fazlasıyla ihtiyaç duymaktadır" diyerek düşüncelerini özetlemiştir. 
Müfredat bağlamında öneri sunan katılımcların bir kısmı ise ortak toplantılar yapılarak ortak bir müfredat geliştirilmesi gerektiğini ifade etmişlerdir. Bu noktada ÖÖ10 “Bu anlamda öncelikle müfredatlarının bölüm başkanları koordinatörlerinin bir araya gelerek belli konularda standartlarmm belirlenmesi gerekiyor. Standartlar üzerinde çeşitli değgişikliklerin yapılması gerekiyor" şeklinde vurgu yaparken ÖÖ5 “Bu noktada yapılması gereken bazı seçmeli dersler dışında diğer derslerin Türkiye geneli ortak bir müfredat belirlenerek yapılmasinda yarar var$d \imath r^{\prime \prime}$ ifadelerini kullanmıştır.

Müfredat bağlamında yerele ve kültüre duyarlılığı ön plana çıkaran ÖÖ6 ise düşüncelerini "Bunun yerine kendi öz kaynaklarmmızan beslenilmeli... Başta aile, kadın, çocuk ve yaşl olmak üzere bütün dezavantajlı kesimlere yönelik çözüm öneri ve stratejileri batı merkezli yerine kendi öz yerel bakış açısı geliştirilerek bunların sunmuş olduğu perspektif eğitim müfredatımıza dâhil edilmelidir... Ayrıca sadece ithal ve çeviriye endeksli dersler değil, yerel toplum ve aile tanımlayacak, öğrencilere farklı bakış açıları kazandıracak çeşitli dersler müfredata kazandırılmalıdır" ş̧eklinde dile getirmiştir.

Tablo 10. YÖK'e ve üniversite yönetimlerine yönelik öneriler

\begin{tabular}{ll}
\hline YÖK ve Üniversiteye & f \\
\hline Öğrenciler mülakat ile alınsın & 1 \\
\hline Açköğretim kapatılsın & 2 \\
\hline Programların açlması durdurulsun & 2 \\
\hline Açma kriterleri zorlaştırılsın & 2 \\
\hline Kent merkezlerinde açılmalı & 2 \\
\hline MYO sosyo-külttürel olanaklar artırılmalı & 1 \\
\hline Lisanslara bölüm açma yetkisi verilsin & 1 \\
\hline Akademisyenler alandan olmalı & 10 \\
\hline Tanıtım faaliyetleri yapilsın & 4 \\
\hline Toplam & 25 \\
\hline
\end{tabular}

Sosyal hizmetler eğitiminin geliştirilmesine yönelik sunulan önerilerin bir kısmı da YÖK ve üniversite yönetimlerine yönelik daha makro önerilerdir. En öncelikli vurgu ise sosyal hizmetler programı öğretim elemanlarının alandan olma gerekliliğidir. Nitekim "Her bölüme alandan en az 1 hoca atanmalı" (ÖÖ2), "Bunun yanında bölüm açmak için alan mezunu akademisyen zorunluluğu getirilmelidir" (ÖÖ6), "Programda görev alan öğretim elemanlarmın sosyal hizmet alanından mezun olanlarndan seçilmesi veya bunlara öncelik verilmesi" (ÖÖ5) ve 
"Kalitenin artırılması için öncelikle yeterli donanıma sahip (en az yüksek lisans mezunu) öğretim elemanlarnnn istihdam edilmesi lazım. Ayrıca alan dışı öğretim elemanlarmmn ilgili programda çalıştırılmaması gerektiğini düşünüyorum" (ÖÖ9) şeklinde öne sürülen düşünceler bu öneriyi göstermektedir.

YÖK ve üniversite yönetimlerine sunulan diğer önerilere ilişkin örnekler şu şekildedir:

- "Aslında bu tarz bölüm ya da programlara öğrenci alıminda mülakat yapılması uygun bir tutum olabilir diye düşünüyorum." (ÖÖ1)

- "Açıöğretimden eğitim alma kapatılmalı. Uygulamah eğitim artırılmalı. Halka basın yaym ve çeşitli yollarla sosyal hizmetin ne olduğu anlatılmalı. Meslek olarak daha güçlü bir lobi oluşturulmalı. Hem kendi alanında yetişmiş birçok hocayla daha fazla etkileşim içerisinde olacak hem kendini daha iyi yetiştirecek en azından 4 yıllığı olan üniversitelere 2 yıllığı açma yetkisi verilsin." (ÖÖ2)

- “Özellikle ilçelerde ön lisans bölümlerinin olmasından kaynaklı Sosyal Hizmet Mezunları bu bölümde akademisyen olmak istemediği için alan dışı akademik personel alınmaktadır. Bu durum eğitim kalitesinin düşürmektedir. Sosyal Hizmet Mezunlarının bu alana sahip çıkması ve bölümlerin şehir merkezlerinde açılarak ilgili uygulama kurumlarıyla beraber çalışmaları önem taşımaktadır." (ÖÖ3)

- "Sosyal hizmet alannnda yetkin akademisyen yetiştirilmesi, ön lisans öğrenci düzeylerine göre müfredat belirlenmesi, açı öğretimlerin kapatılarak eğitimin sadece örgün olarak devam etmesi, iş olanaklarmmn arttırlması ve meslek yüksekokullarmın sosyal ve kültürel benzeri olanaklarmm arttırlmast gibi öneriler sunabilirim." (ÖÖ4)

- Her şeyden önce öğrenci potansiyeli var diye her üniversiteye ve her MYO sosyal hizmetler bölümünün açılması kesinlikle kabul edilemez. YÖK hem bu bölüme ilişkin hem de diğer bölümlere ilişkin daha zorlayıcı kriterler getirmesi gerekmektedir. Bunun yanında sadece teorik değil aynı zamanda uygulamalı bir bilim olan sosyal hizmet alandan çok ciddi anlamda beslenmeli, Aile, Çalışma ve Sosyal Hizmetler Bakanlı̆̆ı ve diğer ilgili bakanliklarla ortak projeler geliştirilerek alanda yaşanan gelişmeler müfredata entegre edilmelidir." (ÖÖ6) 
Tablo 11. İstihdama yönelik öneriler

\begin{tabular}{ll}
\hline İstihdam & f \\
\hline İşolanakları artırısın & 4 \\
\hline Atama kriterleri belirlensin & 2 \\
\hline Kimlik sorunu çözülmeli & 3 \\
\hline İgili uygulama kurumlarıla beraber çalısma & 4 \\
\hline Mesleki lobi oluşturulmalı & 1 \\
\hline Toplam & 14 \\
\hline
\end{tabular}

İstihdam bağlamında da katılımcıların çeşitli önerileri vardır. Buna ilişkin örnekler şöyledir:

- “Ön lisans eğitimle ilgili atama kriterlerin belirlenmesi ve ön lisans atamalarryla ilgili gerekli düzenlemelerin yapılması, eğitim alanındaki programları atama yapılabilecek alanlardaki uygulamalar dikkate alnarak revize edilmesi eğitimin ve mezunlarn kalitesini artıracaktır." (ÖÖ8)

- "Sorunlara tek tek değinmek gerekiyor. Önce sorunlarm halledilmesi gerekiyor. Kimlik sorunu çözülmeli. Biz kimiz nereden ve ne amaçla öğrenci yetiştiriyoruz. Bu öğrenciler mezun olduktan sonra nerelerde nasıl firsatlar elde edecekler... Öğrenci kalitesinin, gelen öğrencinin kalitesini artırmak için sistemi tekrar kontrol edebilmek için istihdam olanaklarını artırlması bu anlamda veya sistemin değiştirilmesi için çalışmalar yapılabilir. Yani daha nitelikli öğrenci gelebilmesi için istihdam sorununa bir şekilde değinilmeli ve bölüm tanıtım programları yapabilmeliyiz. Ön lisans programında olan öğretim elemanları ve bölüm başkanlan ile en az yılda bir kez bir araya gelip çeşitli değerlendirmelerin yapılması, tartışılması ve çeşitli kararların alınması da programın eğitim kalitesini yükselteceği düşüncesi içerisindeyim." (ÖÖ10)

\section{Tartışma, Sonuç ve Öneriler}

Araştırmada sosyal hizmetler programı öğretim elemanlarının sosyal hizmetler eğitimiyle ilgili karşılaştıkları en temel sorunlar, sosyal hizmetler müfredatına yönelik görüşleri ve sosyal hizmetler eğitim kalitesinin artırılmasına yönelik önerileri nitel çalışma ile değerlendirilmiştir.

Araştırma kapsamında öğretim elemanlarına sorulan ilk soru sosyal hizmetler ön lisans eğitimiyle ilgili en temel sorun alanlarının neler olduğudur. Sonuçlar katılımcların büyük çoğunluğunun; staj ve müfredat sorunu, teo- 
rik - uygulama uyuşmazlığı ve kaynak kitap sıkıntısı gibi alt alanlardan oluşan eğitimin içeriğiyle ilgili en sık karşılaştıkları sorun alanı olduğunu göstermektedir. Kaynak kitap sıkıntısı bağlamında sosyal hizmetler ön lisans eğitiminde okutulacak kitap sayısının çok sınırlı olduğu ve var olan diğer kaynakların ise sosyal hizmet lisans bölümlerinde okutulan kaynaklardan oluştuğu ifade edilebilir.

Staj ve uygulama sorunu da eğitimde karşılaşılan bir sorundur. Göktürk ve arkadaşlarına (2013) göre bu durum tüm sosyal bilimler alanında eğitim veren meslek yüksekokullarının ortak sorunudur. Ülkemizde MYO'lar uygulama eğitimi açısından yeterli imkânlara sahip değildirler. Sosyal hizmetler programı bağlamında ise öğrencilerin uygulamayı en iyi biçimde gerçekleştirecek şekilde yetiştirilmeleri açısından staj yapması, teorik dersler kadar önem verilmesi gereken bir konudur. Öğrenciler sosyal hizmetler alanlarında yapacakları stajlarda; edindikleri teorik bilgilerini hayata geçirme, mesleki kültüre uyum sağlama, daha yaratıcı düşünme, bilgi seviyesini artırma imkânı bulmaktadırlar. Ancak öğretim elemanları staj yaptıracak kurum ve kuruluş bulamadıklarını veya öğrencilerin staj yaptıkları birimlerde çok tanınmadıkları ve dikkate alınmadıklarını ifade etmişlerdir. Staj uygulaması dışında teori ile uygulamanın verilen eğitimde uyuşmazlığ tir.

Staj sorunu bağlamında Oral (2017), Anadolu Üniversitesi Açıöğretim Fakültesi örneği üzerinden sosyal hizmetler ön lisans programı öğrencilerinin staj uygulamalarına ilişkin görüş ve düşüncelerini değerlendirmiştir. Bu çalışmasında, ankete katılan öğrencilerin \%37,6'sının staj yapılacak kurumları bilmediğini, \%51,6'sının staj yeri bulma konusunda sorun yaşadığını, \%33,3'ünün aldığı eğitime uygun bir staj yapmadığını, \%43,0'ünün öğrendiği teorik bilgileri staj yaparken uygulama fırsatı bulmadığını, \%39,8'inin teorik eğitimle kurumlarda yapılan uygulamalar arasında paralellik olmadığını ve \%35,5'inin ise staj yaptığ kurumdaki yetkililerin kendisiyle ilgilenmediğini, bilgilerini ve tecrübelerini paylaşmadığını tespit etmiştir. Ayrıca bu tespitlere ilave olarak öğrencilerin staj yeri bulma konusunda sorun yaşadığı, staj yapmanın zorunlu olması gerektiği ve staj süresinin yetersiz bulunduğu da çalışmanın en önemli sonuçları olarak karşımıza çıkmaktadır.

Sosyal hizmetler eğitiminde karşılaşılan sorunlardan diğeri görev tanımının, istihdamın ve atamanın olmaması, lisansın alt alanı gibi görünmesi, kimlik ve amaç sorunu gibi alt alanlardan oluşan kimlik ve istihdam sorunudur. 
Mesleki tanımlama ve unvan sorunu bağlamında sosyal hizmetler mezunlarının mesleki unvan, görev ve yetki tanımlarl; kanunlar, kararnameler veya yönetmelikler çerçevesinde mesleki hiyerarşiye uygun bir şekilde belirlenmemiştir. Sosyal hizmetler mezunları Devlet Personel Başkanlığı'nın istihdam politikası içinde henüz mesleki tanım ve istihdam anlamında gerçek yerini bulamamıştır (Apak, 2019). Unvan ve yapacakları işlerin muğlaklığı, eğitimde karşılaşılan çeşitli problemleri de doğurmuştur.

Yarcı ve Alpman'a (2015) göre ise sosyal hizmetler mezunu bireyler meslek görevlerinin net olmaması, eğitim ve istihdam işbirliğinin olmaması ve bireysel motivasyon eksikliği gibi mikro, mezzo ve makro sorunlar yaşamaktadırlar. Ayrıca mesleki tanımlamadaki muğlaklık, atanma prosedürlerinin belirsizliğini de doğurmuştur. Kamu Personeli Seçme Sınavı (KPSS) sürecinde belli bir kategori içerisinde değerlendirilmeyen sosyal hizmetler mezunları için çalışma sahası ciddi bir belirsizlik içermektedir. Böylelikle atanma kriterlerinin oluşmaması, KPSS gibi sınavların istihdam yaratmamasının ve çalışma sahası içerisindeki tanımsızlığın sebep olduğu belirsizlikler yaşanmaktadır. Mesleki ve görev tanımlaması olmayan ve istihdam, atama, iş imkânları vb. olanakların zayıf olması eğitimde bir sorun olarak algılanmaktadır.

İşsizlik ve istihdam sorunu sosyal hizmetler mezunu bireylerin karşılaştığı sorunların başlarında gelmektedir. Bu bağlamda yapılan çalışmada akademisyenlerin büyük çoğunluğu işsizlik sorununun yaşanmasında eğitim kalitesinin de etkisinin olduğu sonucuna ulaşılmıştır. Eğitim etkisini ise daha çok eğitimin var olduğu sisteme bağlamaktadırlar. Mevcut öğrenci sayısının \%80'inden fazlasının açı öğretimdeki sosyal hizmetler programlarına kayıtlı oluşu, kontrolsüz bir şekilde binlerce mezun verilmesi, akademisyenlerin işlerini yeterince doğru yapmamaları ve özverili çalışmamaları ve bununla birlikte öğrencilerin de kendilerini geliştirmemeleri sosyal hizmetler eğitiminin işsizliğe dolaylı etkisinin olduğunu göstermektedir. Herhangi bir ülkede, eğitim alan nüfusun bir işte çalışıyor olması beklenir. Ancak günümüzde Türkiye'de istihdam edilenlerin çoğu, eğitim gördüğü meslek alanında çalışmamaktadır. Bu sebeple temel sorunlardan belki de en önemlisi, eğitim ile istihdam arasında gerekli bağlantının sağlıklı olarak kurulmamış olmasıdır (Muslu, 2010: 34). Ayn sorunu, sosyal hizmetler programindan mezun olan bireylerde de görmek mümkündür. 
Meslek yüksekokulları, verdiği iki yıllık teorik ve uygulamaya dayalı eğitim ile bireyleri, mesleki yaşantılarına hazır hâle getirmektedir. MYO'lar iş ve istihdam kapısını aralayan bir yükseköğrenim kurumudur. Türkiye'de MYO mezunları hem özel hem de kamu istihdamı noktasında payını gün geçtikçe artırmaktadır. Ancak bu durum sosyal hizmetler mezunları için ne yazık ki böyle değildir. Sosyal hizmetler programının sayısında ve kontenjanlarında yaşanan hızlı artış ve bunun yanı sıra açı öğretim programlarında on bini aşkın kontenjan, var olan eğitimin işsizliğe etkisini bariz bir şekilde göstermektedir. 2013-2014 eğitim döneminde sosyal hizmetler programı öğrencisi 95.147 iken; bu sayı ciddi bir artış göstererek 2017-2018 eğitim öğretim yılında 183.902 sayısına ulaşmıştır. 2017-2018 eğitim döneminde sosyal hizmetler ön lisans programına 31.072 öğrenci yeni kayıt yapmıştır (ÖSYM, 2018). Bu bağlamda verilen eğitimini kalitesinin artması istihdamı artıracak ve işsizliği azaltacak bir etkiye sahiptir. Sosyal hizmetler alaninda eğitim veren programların çok sayıda açılması, bu alanda duyulan iş gücü kapasitesini yükseltmeyi hedeflemektedir. Ancak bu denli yaratılan arza ve ihtiyacın çok üzerinde mezun verilmesine karşılık istihdam sayısı oldukça düşük düzeydedir (Apak, 2019).

Araştırma kapsamında sorulan bir diğer soru, akademisyenlerin çalıştıkları sosyal hizmetler programı müfredatını yeterli görüp görmedikleri üzerinedir. Sonuçlar, öğretim elemanlarının çoğunluğunun $(n=6)$ müfredatlarını yetersiz gördüğünü göstermektedir. Sosyal hizmetler müfredatını yetersiz gören katılımcıların görüşleri daha çok teorinin yoğun olması, müfredatın özgün ve öğrenci profiline uygun olmaması, öğrencilerin uygulama derslerinde danışmanlık yapacak süpervizör eksikliği ve müfredatlar arası farklılıklar üzerinden şekillenmiştir.

Sosyal hizmetler ön lisans programında zorunlu, seçmeli derslere ve genellikle staja yer verilmektedir. Bunun yanında, öğrenciler seçmeli dersler de almaktadır. Dersler, kuramsal ve uygulamalı olarak yürütülmektedir. Bu programda ağırlıklı olarak sosyal çalışma, sosyoloji, psikoloji ve iletişim bilimlerinin dersleri okutulmaktadır. Programda yer alan dersler ve öğretim yöntemleri, alanla ilgili kuramsal bilgiyi vermenin yanı sıra, bu bilgileri pratik alana aktarma becerisi de kazandırmaya çalışmaktadır. Her ne kadar programların müfredat içeriğinde uygulama derslerinin olduğu görülse de öğretim elemanları teorik derslerin yoğunlukta olduğunu ifade etmiş ve bu nedenle müfredatı yetersiz görmüşlerdir. MYO'lar teorik eğitimin yanında, 
uygulama ağırlıklı eğitim ve öğretim veren kurumlardır. Sosyal hizmetler programı bağlamında da öğrencilerin uygulamayı en iyi biçimde gerçekleştirecek şekilde yetiştirilmeleri gerekmektedir.

Müfredatın özgün olmaması bağlamında ise ön lisans düzeyinde takip edilen müfredatın içerik olarak lisans düzeyinde verilen sosyal hizmet müfredatına yakın oluşu dile getirilmiştir. Birçok programın müfredatı hazırlanırken sosyal hizmet lisans müfredatının kısaltılmışı/minimize edilmişi şeklinde bir tasarım yapılmıştır. Burada sosyal hizmetler ön lisans programlarında sunulmakta olan eğitim-öğretim müfredatı çoğu zaman sosyal hizmet lisans düzeyi müfredatını kendisine örnek almaktadır. Bu bağlamda; mesleki kimlik sorununu derinleştiren, öğretim elemanlarını ve öğrencileri zor durumda bırakan mevcut müfredat içeriğinin ön lisans eğitiminin amaciyla bağlantılı, uygun ve tutarlı hale getirilmesi dile getirilmesi gereklidir (Sosyal Hizmetler Ön Lisans Programları Çekirdek Eğitim Programı ve Güncel Konular Çalıştayı Sonuç Raporu, 2017). Müfredatın daha iyi seviyelere getirilmesi için özgün bir niteliğe erişmelidir.

Katılımcılar müfredatlar arası farklılıklar bağlamında da sosyal hizmetler müfredatını yetersiz görmektedirler. Sosyal hizmetler programlarının müfredatları arasında ortaya çıan belirgin farklar, sosyal hizmetler yardımclarının hangi niteliklere sahip olmaları gerektiği noktasında da belirsizliğin varlığını gündeme getirmektedir (Yarcı ve Alpman, 2015). Müfredat farklılıklarının olmasının ana nedenlerinden biri sosyal hizmetler programlarının çok farklı akademik birimlerin (sosyal bilimler meslek yüksekokulu, sağlık bilimleri yüksekokulu vb.) bünyesinde açıldığıdır. Farklı isimlere sahip akademik birimlerin içerisinde programların açlması, sosyal hizmetler müfredatında farklılıkların ortaya çıkmasına sebep olabilmektedir. Örneğin sağlık meslek yüksekokulu çatısı altında bulunan bir sosyal hizmetler programında, sağlık alanıyla ilgili dersler daha ağırlıklı olarak bulunurken sosyal bilimler meslek yüksekokulunda bulunan sosyal hizmetler programlarında, sosyal bilimler (psikoloji, sosyoloji gibi) derslerinin ağırlıklı olduğu ifade edilebilir (Apak, 2018). Bir diğer neden ise sosyal hizmetler programlarının bir program olarak ortaya çıkışının nispeten yeni olması ve henüz eğitim ve müfredat kimliğinin net olarak oluşmadığı ve özgünlüğe kavuşamadığı gerçeğidir.

Araştırma katılan öğretim elemanlarının hepsi en az bir kere de olsa müfredatlarını revize ettikleri sonucuna ulaşılmıştır. Bazı katılımcıların ise bu re- 
vizeyi birden çok şeklinde yaptıkları da görülmüştür. Bu durum sosyal hizmetler müfredatı ile ilgili henüz bir netleşmeye gidilmediği ve müfredat denemelerinin devam ettiğini göstermektedir. Bu müfredatların bir yazı tahtasına dönme tehlikesini içinde barındırmaktadır.

Öğretim elemanlarının sosyal hizmetler programı müfredatını revize kriterlerini daha çok öğrenci merkezli bakış açısının ön planda olduğu görülmektedir. Burada daha çok öğrencilerin gelecekteki mesleki yaşamlarında faydalı olmaları ve daha iyi eğitim almaları görüşü hâkimdir. Müfredat geliştirilirken sosyal hizmetler öğrencilerinin teknik becerilerin yanında, sosyal beceriler noktasında da donanımlı olmalarının şart olduğu bir müfredat tasarlanmalı ve kazandırılmalıdır (Yarcı ve Alpman, 2015). Ayrıca Sosyal hizmetler programlarının müfredatları sosyal hizmetler sektörünün (özel, kamu ve STK da dâhil olmak üzere) talepleri göz önüne alınarak yeniden düzenlenmeli ve değişen taleplere göre sürekli olarak güncellenmelidir.

Dikey Geçiş Sınavı'nın (DGS) müfredat değişikliği yapılırken bir kriter olarak gündeme alındığı sonucuna da ulaşılmıştır. DGS, MYO mezunlarına lisans eğitimine devam etme şansı tanıyan bir sınavdır. Böylelikle öğrenciler lisans programlarının kontenjanının \%10'una denk gelecek şekilde geçiş yapabilmektedirler (Günay ve Özer, 2016). Sosyal hizmetler programından mezun öğrencilere de lisans eğitimine dâhil olma hakkı tanınmaktadır. Sosyal hizmet lisans bölümüne sosyal hizmetler ön lisans programı dâhil birçok ön lisans programından DGS ile geçiş hakkı tanınmaktadır. Sosyal hizmetler ön lisans programı dışında bu programların büyük çoğunluğu (Güvenlik ve Koruma, Hava Savunma, İstihbarat, İtfaiyecilik ve Sivil Savunma vb.) ile sosyal hizmet lisans bölümü arasında hiçbir ilişki yoktur (Alptekin, Topuz ve Zengin, 2017). Sosyal hizmetler ön lisans öğrencileri, meslek yüksekokullarındaki eğitimlerini tamamladıklarında ön lisans diploması almaya hak kazanırlar ve isterlerse DGS'ye girmek koşuluyla sosyal hizmet veya sosyoloji lisans bölümlerine kayıt yaptırarak lisans tamamlama imkânına sahip olabilmektedirler (Apak, 2018). Yapılan bir araştırmada (Apak, 2019) öğrencilerin \%87,3 gibi büyük çoğunluğunun dikey geçiş sınavı ile lisans eğitimine devam etmek istedikleri tespit edilmiştir. Bu bağlamda akademisyenlerin müfredat revizelerini gündeme alırken DGS'de geçiş yapacakları sosyal hizmet lisans müfredatından çok ayrı düşmek istememektedirler. Ancak bu durum müfredatın özgünlüğü ve yetişecek sosyal hizmetler yardımcılarının iyi yetiştirilmesi önünde bir engel olabilmektedir. Ayrıca MYO'larda var olan sosyal hizmetler 
programı asıl misyonundan kopup sadece bir transfer niteliği (Apak, 2019) taşıyıp sosyal hizmet lisans bölümlerinin alt eğitim düzeyi gibi algılanmasına neden olabilir.

MYO mezunu meslek elemanlarına verilen eğitim ve öğrenim kalitesinin artırılmasının, ülke ekonomisine verimlilik açısından çok büyük etki yapacağı düşünülmektedir. Öğrencilerin yeterli bilgi ve deneyime sahip olması, milyonlarca iş saatinin kayıp olmaktan çıkıp bir kazanca dönüşmesine olanak sağlamaktadır (Ünver, Yaylı ve Ceylan, 2009). Bu durum sosyal hizmetler alanları için de aynı şekildedir. Öğretim elemanlarının sosyal hizmetler eğitim kalitesinin artırılmasına yönelik en fazla müfredata ilişkin önerilerinin olduğu bunun yanında YÖK'e, üniversite yönetimlerine ve istihdama yönelik önerilerin de olduğu görülmektedir. Apak (2019) çalışmasında sosyal hizmetler programının eğitim kalitesinin artırılmasına yönelik önerilerini araştırmamıza benzer bir şekilde (1) arz-talep dengesinin kontrol edilmesi, (2) sosyal hizmetler programı mezunlarının lisans tamamlama imkânlarının iyileştirilmesi, (3) öğretim elemanlarının niteliğinin artırılması ve (4) güncel ve çağdaş bilgi ile destekleneceği bir eğitim sisteminin olması şeklinde sıralamıştır.

Müfredat bağlamında dile getirilen önerilerin başında uygulama dersleri daha fazla olması ve ortak müfredatların sosyal hizmetler programında var olması gerekliliğidir. YÖK ve üniversite yönetimlerine yönelik önerilerin başında ise sosyal hizmetler programında çalışan akademisyenlerin mutlaka alandan olması gerektiği vurgusu ve öğrenci sayısının azaltılmasına yönelik (açıöğretimin kapatılması, yeni programların açılmasının durdurulması veya açma kriterlerinin zorlaştırılması) teklifler sunmaktadırlar.

Meslek yüksekokullarının en temel sorunlarından biri öğretim elemanı teminidir. Bu sorun hem nitel hem de nicel boyutta önem arz etmektedir. Nicel olarak öğretim elemanlarının sayısının azlığıyla ilişkilidir. Bu durum doğal olarak öğretim elemanlarının yüklerini artırmakta, kendilerini başta mesleki olarak geliştirmeleri için yeterli zaman bulamamasına ve öğrencilerle gerektiği kadar ilgilenememesine neden olmaktadır. Bu da dolaylı olarak niteliği düşürmektedir. Bunun yanında bazı yüksekokullarda öğretim elemanı eksikliği temin edilen ve yarı zamanlı olarak görevlendirilen öğretmenler arac1lığıyla yürütülmektedir (Alkan, Suiçmez, Aydınkal ve Şahin, 2014). Bu durum sosyal hizmetler programında da bariz bir şekilde görülmekte ve sosyal hizmetler tecrübesi olmayan bireylerin öğretim elemanı olarak çalışmalarına imkân tanınmaktadır. 
Eğitim kalitesinin önündeki engellerden biri de istihdamdır. İstihdam durumu netleşmeyinceye kadar öğrenci ve eğitim kalitesi de yükselmeyecektir. İstihdama yönelik öneriler bağlamında da daha çok mezun bireylerin kim olduğu ve nerelerde ne olarak çalışacağı sorularını merkeze alarak mesleki bir kimliğin oluşturulması gerekliliği vurgusu vardır. Eğer sosyal hizmetler mezunu bireylerin kim olduğu sorusunun yanıtı net olarak verilirse istihdamın önündeki en büyük bariyer de ortadan kalkacaktır.

Bu çalışmada ön lisans sosyal hizmetler eğitiminde yaşanan sorunlar, müfredat durumu ve eğitim kalitesinin geliştirilmesi yönelik önerileri ne olduğu sorularına cevaplar bulunmaya çalışılmıştır. Ön lisans mezunu sosyal hizmetler yardımcıları çalışacakları alanlarda büyük bir boşluğu dolduracaklardır ancak tartışılması gereken asıl konu bu bireylerin nasıl daha iyi eğitilmeleri gerekliliğidir. İşte bu çalışma bu soruya öğretim elemanları gözüyle bir katkı sağlamaya çalışmıştır. Öğretim elemanlarının görüşlerinin önemsenmesi gerekliliği sosyal hizmetler eğitiminde verimin artması açısından önemlidir.

Araştırma sonucunda elde edilen bulgular doğrultusunda sunulabilecek bazı öneriler şu şekildedir:

- Sosyal hizmetler programları bölüm başkanlarının ortak katılımıyla toplantılar yapılabilir ve bu toplantılar sonucu zorunlu dersler bağlamında ortak bir müfredat geliştirilebilir.

- Kimlik ve istihdam bağlamında sosyal hizmetler mezunlarının mesleki unvanları netleştirilmelidir.

- Kaynak kitap sorunu bağlamında özgün, yerel ve ara elemanların sosyal hizmet alanlarında daha aktif çalışmalarını sağlayacak eserler ortaya çıkarılması gerekliliği önerilebilir.

- Müfredatlarda uygulama dersleri artırılmalı ve staj sorunu yaşayan programların kamu kurum ve kuruluşlar başta olmak STK, yerel yönetimler ve özel işletmelerle ortak toplantılar yapması ve yöneticilerinin stajın önemi konusunda bilgilendirilmesi gerekliliği önerilebilir.

- Çalışmanın, öğrencilerin bakış açısından da derinlemesine çalışılması önerilebilir.

- Bu çalışma daha büyük bir öğretim elemanı grubuyla nicel olarak yapılabilir. 


\title{
EXTENDED ABSTRACT
}

\section{Problems Encountered in Associate Degree Social Services Education and Curriculum}

\author{
Hidır Apak \\ Mardin Artuklu University
}

Vocational schools; are higher education institutions that give associate degree, aim to train qualified intermediate manpower for certain professions and continue education for two years (YÖK, 1981). Social services program is one of many programs established within vocational schools.

Social services program; is a diploma program in the field of social services that train intermediate staff on the basis of professional qualifications, who are trained at associate level, gain professional skills and experience, and have the responsibility to do their profession within the framework of legal competencies (Apak, 2019). Social studies associate degree is an education level with examples all over the world in accordance with education systems (Tomanbay, 2011, p. 5).

Social services program in Turkey was established in 2008 for the first time at Anadolu University Open Education Faculty. It aims to increase the qualifications of intermediate staff working in the field of social services and to train new intermediate staff needed (Çay, 2011; Oral, 2017). This program has achieved a significant increase both in the context of open education and in formal education after 2013.

There are many studies dealing with the problems encountered in the education of the programs in vocational schools in our country (Göktürk, Aktaş \& Göktürk, 2013; Küçükgöksel \& Akpınar, 2016; Türkeri, 2014; Uçar \& Özerbaş, 2013; Yıldırım, Sertel \& Özmen-Akyol, 2017). However, in this context, no study related to the social services program has been encountered.

In order to improve the social services program, there is a need to identify existing and potential problems and suggestions for solutions. In this context, the opinions of the instructors about the current problems related to education and curriculum are important. Based on all these thoughts, this study aims to reveal in depth the problems, curriculum status and suggestions of 
the social services education from the point of view of lecturers who are working in associate degree social services programs.

Studies on social services associate degree education in our country (Apak, 2018; Tomanbay, 2011; Yarc1 \& Alpman, 2015) are still insufficient. In these studies, the problems encountered in the education and curriculum of social services programs were not addressed. The aim of this study is to try to make contribution to the literature by considering the limitations of the study in this field.

Qualitative method was preferred in the research since it was necessary to include the experiences and thoughts (Büyüköztürk, Kılıç-Çakmak, Akgün, Karadeniz \& Demirel, 2015, p. 243) of teaching staff about social services education. "Maximum diversity sampling", which is one of the purposeful sampling methods, was used in the research. The study group consists of 10 lecturers who volunteered to participate in the study. The data collection tool is a structured interview form prepared by the researcher. After qualitative interviews, data analysis was conducted and firstly interviews and notes were decoded. The obtained notes were examined by content analysis technique.

As a result of decoding the data obtained from the lecturer participating in the research, three general themes were revealed. These general themes are basic problems encountered in social services education, views on the social services curriculum, and suggestions for improving the quality of social services education.

The first question asked to the academic staff within the scope of the research is what the main problem areas related to social services undergraduate education are. The vast majority of the academic staff participating in the research explained the problems encountered under the categories of "content of education", "identity and employment", "academician centered", "YÖK centered" and "student centered".

The majority of lecturers see their curriculum as inadequate. The views of the participants, who saw the social services curriculum as inadequate, were mostly in the context of the theory being intense. All of the respondents stated that they revised their curriculum at least once. It was found that the most suggestions for improving the quality of social services education, recommendations for YÖK and university administrations and employment.

Associate degree social services assistants will fill a huge gap in their fields of work, but the main issue to be discussed is how these individuals should 
be better educated. This study tried to contribute to this question from the perspective of lecturers. The necessity of considering the opinions of the academic staff is important in terms of increasing efficiency in social services education.

Some suggestions that can be presented in line with the findings obtained as a result of the research are as follows: Meetings can be held with the joint participation of department heads of social services programs, and a common curriculum can be developed in the context of compulsory courses as a result of these meetings. Also in the context of identity and employment, the professional titles of social service graduates should be clarified.

\section{Kaynakça / References}

Alkan, R. M., Suiçmez, M., Aydınkal, M. ve Şahin, M. (2014). Meslek yüksekokullarındaki mevcut durum: sorunlar ve bazı çözüm önerileri. Yükseköğretim ve Bilim Dergisi, 4(3), 133-140.

Alptekin, K., Topuz, S. ve Zengin, O. (2017). Türkiye'de sosyal hizmet eğitiminde neler oluyor? Toplum ve Sosyal Hizmet, 28(2), 50-69.

Apak, H. (2018). Geçmişten günümüze Türkiye'de ön lisans sosyal hizmetler eğitimi. Yükseköğretim ve Bilim Dergisi, 8(2), 236-244.

Apak, H. (2019). Sosyal hizmetler ön lisans eğitimi ve ara elemanlar. Ankara: Pegem Akademi.

Bozkurt, Y. ve Şener, G. (2013). Üniversite öğrencilerinin profilini belirlemeye yönelik bir araştırma: Meslek yüksekokulu ve fakülte öğrencilerinin karşılaştırılması. Erciyes İletişim Dergisi "akademia", 3(1), 94-108.

Büyüköztürk, Ş., Kılıç-Çakmak, E., Akgün, Ö. E., Karadeniz, Ş. ve Demirel, F. (2015). Bilimsel araştırma yöntemleri. Ankara: Pegem Akademi.

Creswell, J. W. (2014). Araştırma deseni: Nitel, nicel ve karma yöntem yaklaşımları (S. B. Demir, çev). Ankara: Eğiten Kitap.

Çay, M. (2011). Açıöğretim fakültesi (2 yıllık) sosyal hizmet bölümü hakkında genel bilgiler ve sık sorulan sorular, 25.11.2018 tarihinde http://goo.gl/MV2wXU adresinden erişilmiştir.

Durnalı, M., Orakcı, Ş., ve Özkan, O. (2018). Turkey's higher education potential for human capital of Eurasian Region. In O. Karnaukhova, A. Udovikina, \& B. Christiansen (Eds.), Economic and geopolitical perspectives of the Commonwealth of Independent States and Eurasia içinde (s. 201-224). Hershey, PA: IGI Global. doi:10.4018/978-1-5225-3264-4.ch009 
Ergin, A. ve Yağcı, Ö. (2003). 4702 sayılı yasa çerçevesinde gerçekleştirilen MEB-YÖK meslek yüksekokulları projesine yönelik bir değerlendirme. Hacettepe Üniversitesi Ĕ̆itim Fakültesi Dergisi, 25, 256-264.

Göktürk, İ. E., Aktaş, M. A. ve Göktürk, Ü. (2013). Sosyal bilimler meslek yüksekokullarının eğitim sürecinde; uygulama açısından karşılaşılan sorunlar ve çözüm önerileri. Electronic Journal of Vocational Colleges, UMYOS Özel Sayı, 1-8.

Günay, D. ve Özer, M. (2016). Türkiye'de meslek yüksekokullarının 2000'li yıllardaki gelişimi ve mevcut zorluklar. Yükseköğretim ve Bilim Dergisi, 6(1), 1-12.

Küçükgöksel, N. Ç. ve Akpınar, T. (2016). İstihdam odaklı mesleki eğitime yönelik sorunlar, talep ve beklentiler. Tekirdă̆ SMMMM Odası Sosyal Bilimler Dergisi, 6, 1-18.

Kümbetoğlu B, (2012). Sosyolojide ve antropolojide niteliksel yöntem ve araştırma. İstanbul: Bağlam Yayıncılık.

Muslu, A. (2010). Türkiye'de mesleki eğitim almış nüfusun istihdam sorunları ve çözüm önerileri. Yayınlanmamış Yüksek Lisans Tezi. Sakarya: Sakarya Üniversitesi, Sosyal Bilimler Enstitüsü.

Oral, A. İ. (2017). Sosyal hizmetler ön lisans programı öğrencilerinin staj uygulamalarına ilişkin görüş ve düşüncelerinin değerlendirilmesi: Anadolu Üniversitesi Açıöğretim Fakültesi örneği. Açıö̆ğretim Uygulamaları ve Araştırmaları Dergisi, 4(3), 62-80.

Ölçme, Seçme ve Yerleştirme Merkezi (ÖSYM) (2018). ÖSYS yükseköğretim programları ve kontenjanları kılavuzu. 03.06.2019 tarihinde https://dokuman.osym.gov.tr/pdfdokuman/2018/YKS/KONTKILAVUZ6082018.pdf adresinden erişilmiştir.

Ölçme, Seçme ve Yerleştirme Merkezi (ÖSYM) (2019). ÖSYS yükseköğretim programları ve kontenjanları kılavuzu. 07.08.2019 tarihinde https://www.osym.gov.tr/TR,16858/2019-yuksekogretim-programlari-ve-kontenjanlari-kilavuzu.html adresinden erişilmiştir.

Sosyal Hizmet Okulları. (2017). Sosyal hizmetler ön lisans programları çekirdek eğitim programı ve güncel konular çalıştayı sonuç raporu 7-8 Nisan 2017. Süleyman Demirel Üniversitesi Eğirdir Sağlık Hizmetleri Meslek Yüksekokulu, Isparta. 17 Kasım 2017 tarihinde http://www.sosyalhizmetokullari.org/OnLisansSHProgCalistaySonucRaporu.pdf adresinden erişilmiştir. 
Tomanbay, İ. (2011). Sosyal hizmetlerde açı̈öğretim ve ara elemanlar: Sosyal çalışma ve sosyal teknikerlik. Ankara: SABEV Yayınları.

Türkeri, İ. (2014). Yükseköğretim düzeyinde turizm eğitiminin özel nitelikli sorunları ve çözüm önerileri. Mehmet Akif Ersoy Üniversitesi Eğitim Bilimleri Enstitüsü Dergisi, 3(4), 1-14.

Uçar, C. ve Özerbaş, M. A. (2013). Mesleki ve teknik eğitimin dünyadaki ve Türkiye'deki konumu. Ĕğitim ve Öğretim Araştırmaları Dergisi, 2(2), 242- 253.

Ünver, H. M., Yaylı, H. ve Ceylan, H. (2009). Taşra meslek yüksekokullarının sorunları ve çözüm önerileri. 1. Uluslararası 5. Ulusal Meslek Yüksekokulları Sempozyumu (3063-3070). Konya: Selçuk Üniversitesi.

Yarcı, S. ve Alpman, P. S. (2015). Sosyal hizmet ve danışmanlık bölümü öğrencilerinin istihdam sorunları. Electronic Journal of Vocational Colleges, 5(5), 123-129.

Yıldırım, H., Sertel, E. ve Özmen-Akyol, S. (2017). Meslek yüksekokullarının güncel sorunlarına ilişkin öğretim elemanlarının görüşleri. Mehmet Akif Ersoy Üniversitesi Sosyal Bilimler Enstitüsü Dergisi, 9(21), 287-300.

Yıldırım, A. ve Şimşek, H. (2013). Sosyal bilimlerde nitel araştırma yöntemleri. Ankara: Seçkin Yayınları.

Yükseköğretim Kanunu. (1981). Resmi Gazete, Sayı: 17506.

Yükseköğretim Bilgi Yönetim Sistemi (2019). 07.08.2019 tarihinde https://istatistik.yok.gov.tr/ adresinden erişilmiştir.

\section{Kaynakça Bilgisi / Citation Information}

Apak, H. (2020). Sosyal hizmetler ön lisans eğitimi ve müfredatında karşılaşılan sorunlar. OPUS-Uluslararası Toplum Araştırmaları Dergisi, 15(25), 3382-3414. DOI: 10.26466/opus.668953 